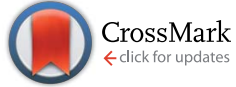

Received 17th June 2015

Accepted 21st August 2015

DOI: $10.1039 / c 5 r a 11599 j$

www.rsc.org/advances
Cite this: RSC Adv., 2015, 5, 74499

\section{The effect of counter ions on the far-infrared spectra of tris(triphenylphosphinegold)oxonium dimer salts $\uparrow$}

\author{
Trystan Bennett, ${ }^{a}$ Alexander J. Falcinella, ${ }^{a}$ Reuben J. White, ${ }^{a}$ Rohul H. Adnan, ${ }^{\text {bc }}$ \\ Vladimir Golovko, ${ }^{\text {b }}$ Gunther G. Andersson*d and Gregory F. Metha*a
}

\begin{abstract}
Two tris(triphenylphosphinegold)oxonium dimer salts $\left[\left\{\left\{\mathrm{Au}\left(\mathrm{PPh}_{3}\right)\right\}_{3}\left(\mu_{3}-\mathrm{O}\right)\right\}_{2}\right]^{2+}\left(\mathrm{X}^{-}\right)_{2}\left(\mathrm{X}=\mathrm{BF}_{4}^{-}, \mathrm{MnO}_{4}^{-}\right)$were investigated via synchrotron-based far-infrared vibrational spectroscopy and density functional theory modelled at the M06/LANL2DZ level of theory. The $50-800 \mathrm{~cm}^{-1}$ region of both oxonium salts is presented, with the spectrum for $\left[\left\{\left\{\mathrm{Au}\left(\mathrm{PPh}_{3}\right)\right\}_{3}\left(\mu_{3}-\mathrm{O}\right)\right\}_{2}\right]^{2+}\left(\mathrm{BF}_{4}^{-}\right)_{2}$ found to possess a large feature at 330.3 $\mathrm{cm}^{-1}$, attributable to counter-ion vibrational modes, which is only predicted upon explicit inclusion of counter-ions in the calculation. A feature around $107 \mathrm{~cm}^{-1}$ observed for the $\left[\left\{\left\{\mathrm{Au}\left(\mathrm{PPh}_{3}\right)\right\}_{3}\left(\mu_{3}-\mathrm{O}\right)\right\}_{2}\right]^{2+}\left(\mathrm{BF}_{4}^{-}\right)_{2}$ infrared spectrum is assigned to 21 distinct vibrational modes arising from $\mathrm{Au}-\mathrm{Au}$ bond stretching and other motions of the Au core. The same feature is predicted to be present within the $\left[\left\{\left\{\mathrm{Au}\left(\mathrm{PPh}_{3}\right)\right\}_{3}\left(\mu_{3}-\mathrm{O}\right)\right\}_{2}\right]^{2+}\left(\mathrm{MnO}_{4}^{-}\right)_{2}$ spectrum but is masked by experimental noise. In the $50-$ $400 \mathrm{~cm}^{-1}$ region, the relative intensities of predicted vibrational modes is found to depend heavily on the presence and nature of the counter-ions, while within the $400-800 \mathrm{~cm}^{-1}$ region, little dependence of the theoretical spectra on the type of counter-ion is predicted. Finally, the dimerization energies of both $\left[\left\{\left\{\mathrm{Au}\left(\mathrm{PPh}_{3}\right)\right\}_{3}\left(\mu_{3}-\mathrm{O}\right)\right\}_{2}\right]^{2+}\left(\mathrm{BF}_{4}^{-}\right)_{2}$ and $\left[\left\{\left\{\mathrm{Au}\left(\mathrm{PPh}_{3}\right)\right\}_{3}\left(\mu_{3}-\mathrm{O}\right)\right\}_{2}\right]^{2+}\left(\mathrm{MnO}_{4}^{-}\right)_{2}$ are calculated to be $3.06 \mathrm{eV}$ and $3.20 \mathrm{eV}$, respectively, when the counter-ions are explicitly included within the calculation, and just $1.10 \mathrm{eV}$ in their absence.
\end{abstract}

\section{Introduction}

The chemistry of univalent gold species has been well studied throughout the past 40 years, ${ }^{1}$ spurred primarily by the work of Nesmeyanov and co-workers. ${ }^{2-7}$ The discovery of the tris(triphenylphosphinegold)oxonium salts of the form $\left[\left(\mathrm{Ph}_{3} \mathrm{PAu}\right)_{3} \mathrm{O}\right] \mathrm{X}$ $\left(\mathrm{X}=\mathrm{BF}_{4}^{-}, \mathrm{MnO}_{4}^{-}, \mathrm{CF}_{3} \mathrm{COO}^{-}\right.$), which have been shown to exist as dimers in the crystalline phase, represented an addition to the few known species which incorporate direct $\mathrm{Au}-\mathrm{O}$ bonding. ${ }^{2,3}$ These oxonium salts have seen employment throughout the literature due to their ability to readily decompose in situ into highly reactive $\mathrm{Ph}_{3} \mathrm{PAu}^{+}$species, ${ }^{7}$ capable of reacting with a wide array of organic species to yield corresponding aurated

${ }^{a}$ Department of Chemistry, University of Adelaide, South Australia 5005, Australia. E-mail: greg.metha@adelaide.edu.au; Fax: +61 88313 4358; Tel: +61 883135943 ${ }^{b}$ The MacDiarmid Institute for Advanced Materials and Nanotechnology, Department of Chemistry, University of Canterbury, Christchurch 8140, New Zealand

${ }^{c}$ Chemistry Department, University of Malaya, 50603 Kuala Lumpur, Malaysia

${ }^{d}$ Flinders Centre for NanoScale Science and Technology, Flinders University, Adelaide, SA 5001, Australia

$\dagger$ Electronic supplementary information (ESI) available: Containing a comparison between the crystallographic and DFT-optimized $\mathrm{Au}_{6} \mathrm{O}_{2}$ core, optimized structures for the $\left[\left[\left(\mathrm{Ph}_{3} \mathrm{PAu}\right)_{3} \mathrm{O}\right] \mathrm{BF}_{4}\right]_{2}$ and $\left[\left[\left(\mathrm{Ph}_{3} \mathrm{PAu}\right)_{3} \mathrm{O}\right] \mathrm{MnO}_{4}\right]_{2}$ species, and a comparison between the theoretical spectra for the $\left[\left(\mathrm{PPh}_{3} \mathrm{Au}\right)_{3} \mathrm{O}\right]^{-}$and $\left(\left[\left(\mathrm{PPh}_{3} \mathrm{Au}\right)_{3} \mathrm{O}\right]^{-}\right)_{2}$ species. See DOI: 10.1039/c5ra11599j derivatives. Oxonium salts have been reported to react with cyclic structures such as cyclopentadiene, tetraphenylcyclopentadiene, and ferrocene, resulting in the substitution of $\mathrm{H}$ by $\mathrm{AuPPh}_{3}{ }^{5,6,8,9}$ They have been reported to react with carboncontaining species such as methyl ketones, vinyl esters and ethers, and chloroform, yielding $\alpha$-aurated species such as aurated acetone, aurated acetaldehyde, and trichloromethyl gold. ${ }^{7}$ Tris(triphenylphosphinegold)oxonium salts have been shown to react with nitrogen-containing compounds such as malononitrile, $N, N$-diethylamides, and dicyanoacetylene to yield gold triphenylphosphine-bound species. ${ }^{2,4,7,10-12}$ The oxonium salts have also been reported to form mixed-metal ligated clusters, with, for example, the species $\mathrm{Au}_{3} \mathrm{CoRu}_{3}(\mathrm{CO})_{12}\left(\mathrm{PPh}_{3}\right)_{3}$ having been synthesized utilizing tris(triphenylphosphinegold) oxonium species as a reagent. ${ }^{\mathbf{1 3}, \mathbf{1 4}}$

Infrared vibrational spectroscopy is a standard technique for probing the unique vibrational fingerprint of a given molecule, which is widely utilized to identify functional groups present within a molecule of interest. For the tris(triphenylphosphategold)oxonium salts, only a rudimentary assignment of the infrared absorption features have been reported, ${ }^{3}$ with no reports of spectra in the far-infrared region below $800 \mathrm{~cm}^{-1}$. This region is of importance to ligated metal cluster species as vibrational modes involving metal-metal stretching appear within this region. ${ }^{15,16}$ We have previously reported the far- 
infrared (50-650 $\mathrm{cm}^{-1}$ ) vibrational spectra of a range of gold, ruthenium, and gold-ruthenium species, which were accompanied by computational investigations to give an insight into the specific vibrational modes which give rise to each feature within the infrared spectra. ${ }^{\mathbf{1 5 , 1 6}}$ For all previous calculations involving species with counter-ions, the counter-ions were removed and the charge balanced for the primary cluster of interest, i.e. the counter-ions were not explicitly calculated.

The present work reports the vibrational spectra of the oxonium salts $\left[\left\{\left\{\mathrm{Au}\left(\mathrm{PPh}_{3}\right)\right\}_{3}\left(\mu_{3}-\mathrm{O}\right)\right\}_{2}\right]^{2+}\left(\mathrm{BF}_{4}^{-}\right)_{2}$ and $\left[\left\{\left\{\mathrm{Au}\left(\mathrm{PPh}_{3}\right)\right\}_{3}\left(\mu_{3}-\mathrm{O}\right)\right\}_{2}\right]^{2+}\left(\mathrm{MnO}_{4}^{-}\right)_{2}$, and utilize density functional theory (DFT) based calculations to assign the infrared features of each of these species to specific molecular vibrational modes. Herein, we demonstrate the importance of including counter-ions within the calculations to explain all observed features within the experimental spectrum. As well, the energies of association of the counter-ions to the gold oxonium species have also been calculated, and are reported. Finally, consistent with literature reports that the salts exist as dimers, ${ }^{3,7}$ the energy of dimerization for both oxonium salts are calculated and presented.

\section{Experimental \& computational procedures}

The $\left[\left\{\left\{\mathrm{Au}\left(\mathrm{PPh}_{3}\right)\right\}_{3}\left(\mu_{3}-\mathrm{O}\right)\right\}_{2}\right]^{2+}\left(\mathrm{BF}_{4}^{-}\right)_{2}$ and $\left[\left\{\left\{\mathrm{Au}\left(\mathrm{PPh}_{3}\right)\right\}_{3}\left(\mu_{3}-\mathrm{O}\right)\right\}_{2}\right]^{2+}$ $\left(\mathrm{MnO}_{4}^{-}\right)_{2}$ clusters were prepared according to the procedures reported by Nesmeyanov et $a .^{3}$ Samples were prepared by pressing varying amounts of cluster into polyethylene (PE) to form a pellet of $7 \mathrm{~mm}$ diameter. Due to the wide range of absorptivity that the clusters exhibited across the measurement window, the spectra were recorded at several dilutions by mass in PE. For $\left[\left\{\left\{\mathrm{Au}\left(\mathrm{PPh}_{3}\right)\right\}_{3}\left(\mu_{3}-\mathrm{O}\right)\right\}_{2}\right]^{2+}\left(\mathrm{BF}_{4}^{-}\right)_{2}$, the spectra reported were recorded with a pure pellet of cluster (solid line in Fig. 1a) and a $1: 3$ cluster : PE (solid line in Fig. 1b) dilution by mass. For $\left[\left\{\left\{\mathrm{Au}\left(\mathrm{PPh}_{3}\right)\right\}_{3}\left(\mu_{3}-\mathrm{O}\right)\right\}_{2}\right]^{2+}\left(\mathrm{MnO}_{4}^{-}\right)_{2}$, the spectra reported were recorded at $1: 1$ cluster : $\mathrm{PE}$ (solid line in Fig. 2a) and $1: 3$ cluster : PE (solid line in Fig. 2b) dilutions by mass.

The far-IR absorption spectra were recorded using the IFS125 Bruker FT spectrometer located at the far-IR beamline, at the Australian Synchrotron. The transmission spectrum for each sample was recorded from 50 to $800 \mathrm{~cm}^{-1}$, at $1 \mathrm{~cm}^{-1}$ resolution utilizing the synchrotron light source (200 $\mathrm{mA}$ in top-up mode), with a 6 micron thick multilayer Mylar beamsplitter in combination with a $\mathrm{Si}$ bolometer detector. This bolometer was equipped with an $800 \mathrm{~cm}^{-1}$ far-IR cut-on cold-filter consisting of a 13 micron PE film overlaid with a 6 micron diamond scatter layer. All spectra were recorded at room temperature, and have been baseline corrected.

Geometry optimization and harmonic vibrational frequency calculations of the $\left[\left\{\left\{\mathrm{Au}\left(\mathrm{PPh}_{3}\right)\right\}_{3}\left(\mu_{3}-\mathrm{O}\right)\right\}_{2}\right]^{2+}\left(\mathrm{X}^{-}\right)_{2} \quad(\mathrm{X}=$ $\mathrm{BF}_{4}^{-}, \mathrm{MnO}_{4}^{-}$) cluster compounds, including all ligands, were undertaken using the M06 density functional, ${ }^{17}$ with all atoms treated using the LANL2DZ basis set and related Effective Core Potentials (ECP) ${ }^{18-21}$ in the Gaussian 09 suite of programs. ${ }^{22}$ This level of theory has been utilized by us for similar ligated metal
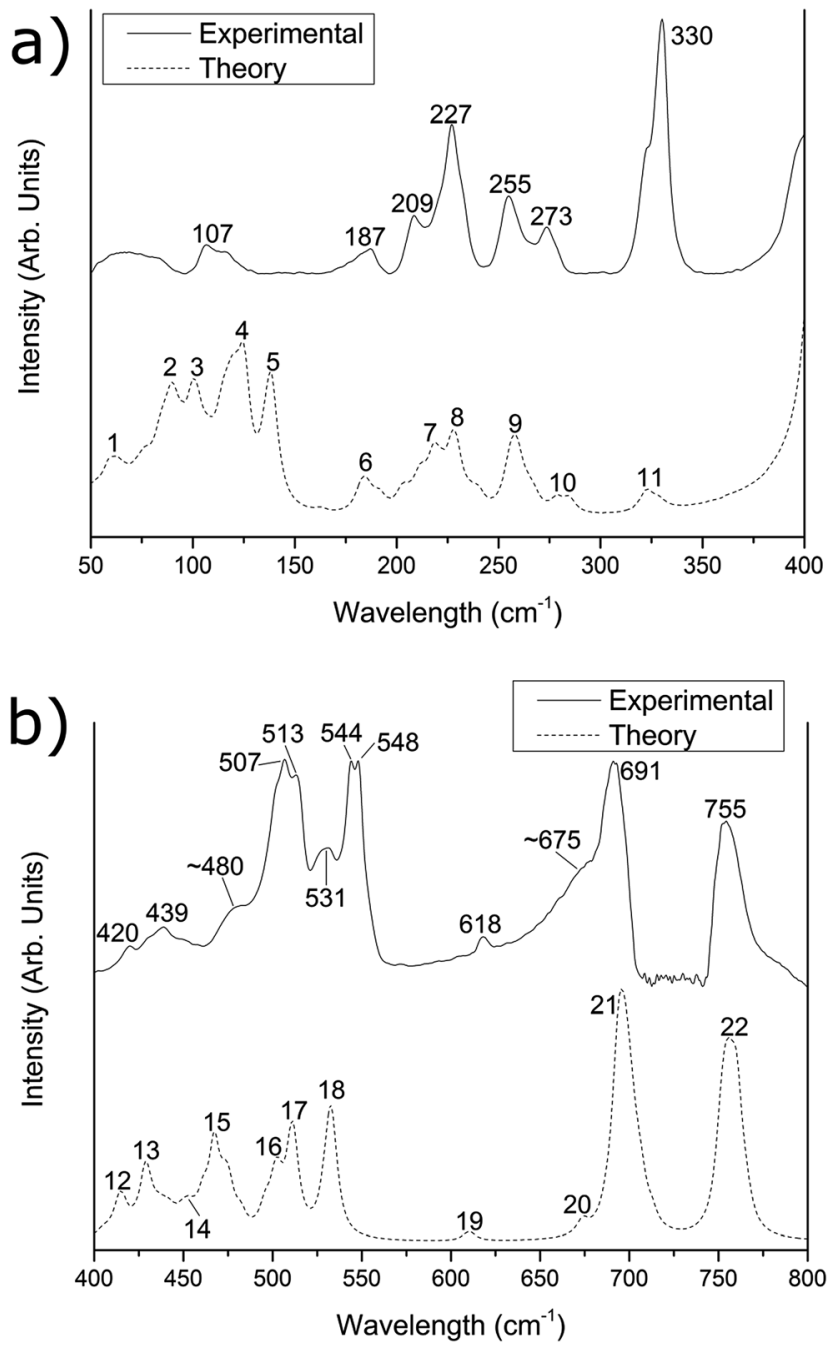

Fig. 1 Experimental (solid line) and simulated (dashed line) far-IR spectra of the $\left[\left\{\left\{\mathrm{Au}\left(\mathrm{PPh}_{3}\right)\right\}_{3}\left(\mu_{3}-\mathrm{O}\right)\right\}_{2}\right]^{2+}\left(\mathrm{BF}_{4}^{-}\right)_{2}$ cluster in the (a) $50-$ $400 \mathrm{~cm}^{-1}$ region and (b) $400-800 \mathrm{~cm}^{-1}$ region. The experimental data was recorded at (a) pure sample and (b) a $1: 3$ sample/PE dilution by mass. The simulated spectrum has been corrected by eqn (1).

cluster systems previously, and has been shown to give good agreement to experimental results. ${ }^{15,16}$ Except where calculating the energy of dimerization, all calculations reported are for the dimer of the $\mathrm{Au}_{3}$ species, i.e. $\left[\left\{\left\{\mathrm{Au}\left(\mathrm{PPh}_{3}\right)\right\}_{3}\left(\mu_{3}-\mathrm{O}\right)\right\}_{2}\right]^{2+}\left(\mathrm{X}^{-}\right)_{2},(\mathrm{X}=$ $\mathrm{BF}_{4}^{-}, \mathrm{MnO}_{4}^{-}$, or nothing), consistent with literature reports. ${ }^{3,7}$ The starting geometry of the $\left[\left\{\left\{\mathrm{Au}\left(\mathrm{PPh}_{3}\right)\right\}_{3}\left(\mu_{3}-\mathrm{O}\right)\right\}_{2}\right]^{2+}$ species without counter-ions were taken from the X-ray crystal structure of the $\left[\left\{\left\{\mathrm{Au}\left(\mathrm{PPh}_{3}\right)\right\}_{3}\left(\mu_{3}-\mathrm{O}\right)\right\}_{2}\right]^{2+}$ cluster with a $N$-(4-methoxyphenyl)-2,4,6trinitroanilate counter-ion (CSD Refcode WAVWUM) ${ }^{23}$ retrieved from the Cambridge Crystallographic Database. ${ }^{24}$ The counterions and solvent molecules were removed from this structure, and electrons removed from the dimer to balance the charge; a comparison between the X-ray crystal structure and the final optimized gas-phase structure is shown in the ESI (Fig. S1 $\dagger$ ). All calculations involving binding energies and energies of dimerization were not corrected for Basis Set Superposition Error (BSSE).

Once the $\left[\left\{\left\{\mathrm{Au}\left(\mathrm{PPh}_{3}\right)\right\}_{3}\left(\mu_{3}-\mathrm{O}\right)\right\}_{2}\right]^{2+}$ structure was optimized, the respective counter-ions (either $\mathrm{BF}_{4}^{-}$or $\mathrm{MnO}_{4}^{-}$) were added 

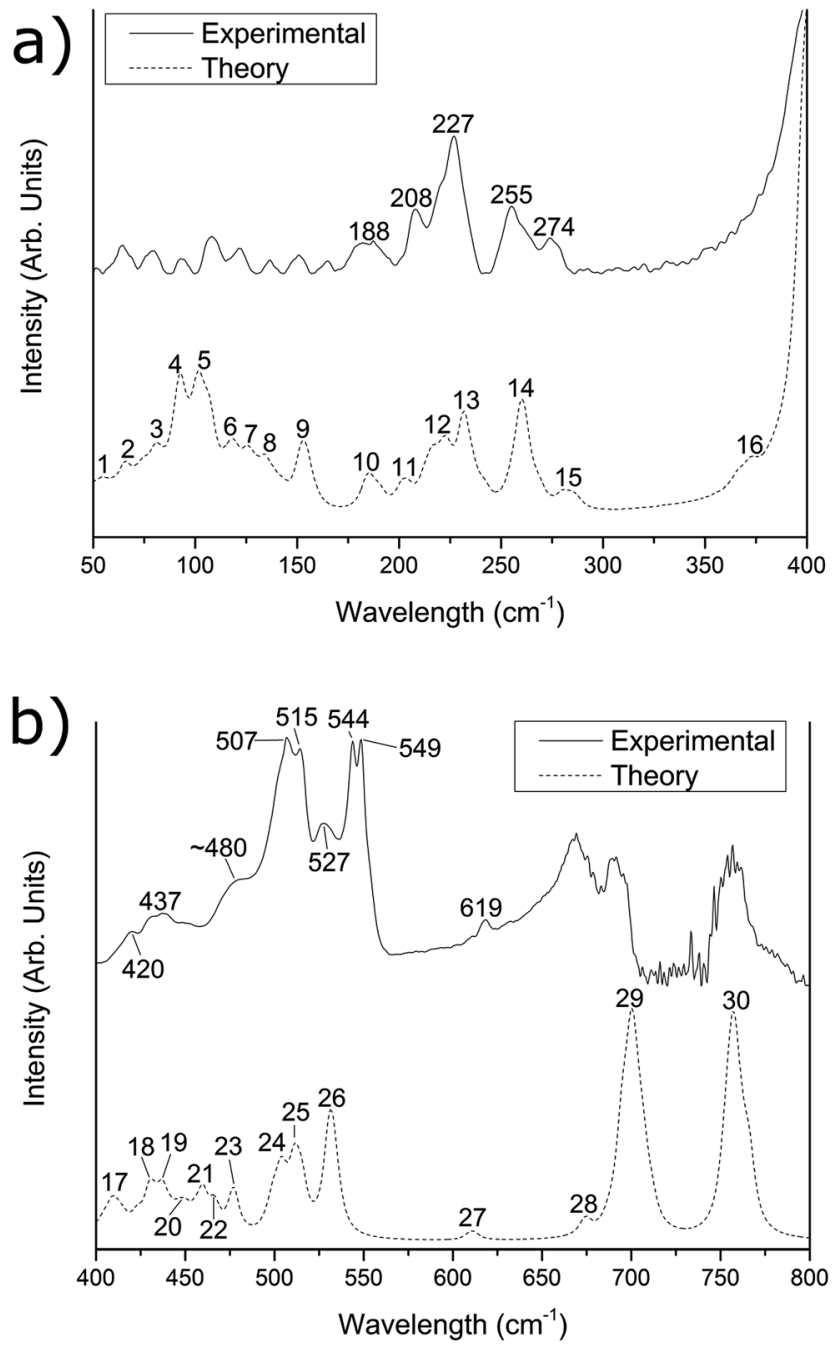

Fig. 2 Experimental (solid line) and simulated (dashed line) far-IR spectra of the $\left[\left\{\left\{\mathrm{Au}\left(\mathrm{PPh}_{3}\right)\right\}_{3}\left(\mu_{3}-\mathrm{O}\right)\right\}_{2}\right]^{2+}\left(\mathrm{MnO}_{4}^{-}\right)_{2}$ cluster in the (a) $50-$ $400 \mathrm{~cm}^{-1}$ region and (b) $400-800 \mathrm{~cm}^{-1}$ region. The experimental data was recorded at (a) a $1: 1$ sample/PE dilution by mass and (b) a $1: 3$ dilution by mass. The simulated spectrum has been corrected by eqn (1).

and this structure was further optimized at the same level of theory. Several potential starting counter-ion positions were investigated, and for each species the global minimum structure was utilized for frequency calculations and analysis. The charge was explicitly held on each molecule within all calculations which included counter-ions, i.e. the $\mathrm{BF}_{4}^{-}$or $\mathrm{MnO}_{4}^{-}$was explicitly held at -1 formal charge, and the $\left[\left\{\left\{\mathrm{Au}\left(\mathrm{PPh}_{3}\right)\right\}_{3^{-}}\right.\right.$ $\left.\left.\left(\mu_{3}-\mathrm{O}\right)\right\}_{2}\right]^{2+}$ species was held at +2 formal charge. All calculations were performed as closed-shell species. The optimizations were all performed in the $C_{1}$ point group, with no potential symmetry identified for all systems.

The calculations were carried out using a larger than default grid (Gaussian keyword "int = ultrafine") for numerical integral evaluation, with all other cut-offs being left at the default. Each geometry optimization was followed by a harmonic frequency calculation to confirm that the geometry was a true minimum with no imaginary frequencies. To obtain the predicted IR spectra, each predicted stick spectrum was convoluted with a Gaussian line shape function with $8 \mathrm{~cm}^{-1}$ full width at half maximum using the GaussView 5 program, to best match the experimental spectra. Full geometric information for each optimized structure is provided in the accompanying ESI. $\dagger$

\section{Results \& discussion}

The predicted spectra over the range $50-800 \mathrm{~cm}^{-1}$ for $\left[\left\{\left\{\mathrm{Au}\left(\mathrm{PPh}_{3}\right)\right\}_{3}\left(\mu_{3}-\mathrm{O}\right)\right\}_{2}\right]^{2+}\left(\mathrm{BF}_{4}^{-}\right)_{2}$ and $\left[\left\{\left\{\mathrm{Au}\left(\mathrm{PPh}_{3}\right)\right\}_{3}\left(\mu_{3}-\right.\right.\right.$ $\left.\mathrm{O})\}_{2}\right]^{2+}\left(\mathrm{MnO}_{4}^{-}\right)_{2}$ are shown in Fig. 1 and 2 as the lower dotted lines. The assignments of peaks observed in the experimental spectra to the theoretically predicted spectra for both clusters are shown in Table 1, along with a breakdown of the major vibrational motions for each feature. These spectra only include the calculated fundamental vibrations and do not include overtones or combination bands. For both Fig. 1 and 2, as well as all values in Table 1, the theoretical infrared spectrum has been scaled by the functional-independent correction factor (eqn (1)) reported by Fielicke and co-workers for low-frequency vibrations predicted by DFT calculations. ${ }^{25}$ This has been used by us previously to obtain better agreement for far-IR transitions than traditional vibrational frequency correction schemes. ${ }^{16}$

$$
\tilde{\nu}_{\text {corr }}=22 \mathrm{~cm}^{-1}+\tilde{\nu}_{\text {calc }} \times 0.94
$$

For Fig. 1 and 2, the theoretically predicted infrared spectra display myriad peaks throughout the $50-800 \mathrm{~cm}^{-1}$ region. All peaks predicted within the spectrum are numbered sequentially, starting at low energy, for both $\left[\left\{\left\{\mathrm{Au}\left(\mathrm{PPh}_{3}\right)\right\}_{3}\left(\mu_{3}-\mathrm{O}\right)\right\}_{2}\right]^{2+}$ $\left(\mathrm{BF}_{4}^{-}\right)_{2}$ (Fig. 1) and $\left[\left\{\left\{\mathrm{Au}\left(\mathrm{PPh}_{3}\right)\right\}_{3}\left(\mu_{3}-\mathrm{O}\right)\right\}_{2}\right]^{2+}\left(\mathrm{MnO}_{4}^{-}\right)_{2}$ (Fig. 2). This peak numbering scheme is the same as that used in Table 1 for the assignments of peaks to predicted vibrational modes. Also shown in Fig. 1 and 2 are the experimental infrared spectra for $\left[\left\{\left\{\mathrm{Au}\left(\mathrm{PPh}_{3}\right)\right\}_{3}\left(\mu_{3}-\mathrm{O}\right)\right\}_{2}\right]^{2+}\left(\mathrm{BF}_{4}^{-}\right)_{2}$ and $\left[\left\{\left\{\mathrm{Au}\left(\mathrm{PPh}_{3}\right)\right\}_{3}\left(\mu_{3}-\mathrm{O}\right)\right\}_{2}\right]^{2+}$ $\left(\mathrm{MnO}_{4}^{-}\right)_{2}$ (represented as the upper solid lines in Fig. 1 and 2, respectively), at varying dilutions by mass with polyethylene (vide supra).

\section{$50-400 \mathrm{~cm}^{-1}$ region}

The experimental spectra of the $\left[\left\{\left\{\mathrm{Au}\left(\mathrm{PPh}_{3}\right)\right\}_{3^{-}}\right.\right.$ $\left.\left.\left(\mu_{3}-\mathrm{O}\right)\right\}_{2}\right]^{2+}\left(\mathrm{BF}_{4}^{-}\right)_{2}$ cluster in the $50-150 \mathrm{~cm}^{-1}$ region (Fig. 1a) contains two main features of interest. Below $100 \mathrm{~cm}^{-1}$, there is a broad, featureless peak with a maximum intensity at $65 \mathrm{~cm}^{-1}$, which we have previously attributed to phenyl group motions that are dampened in the solid phase compared with the gas phase calculation. ${ }^{15}$ The second feature, with maximum intensity at $107 \mathrm{~cm}^{-1}$, is assigned to peak \#4 in the predicted spectrum. This peak arises from a combination of thirteen vibrational motions of varying infrared activity involving motions of the Au core. Based upon our previous work, ${ }^{15,16}$ this peak is expected to exhibit strongly within the experimental spectrum due the high Au core contribution component of $10.6 \%$. The experimental spectrum of the $\left[\left\{\left\{\mathrm{Au}\left(\mathrm{PPh}_{3}\right)\right\}_{3}\left(\mu_{3}-\mathrm{O}\right)\right\}_{2}\right]^{2+}\left(\mathrm{MnO}_{4}^{-}\right)_{2}$ cluster below $150 \mathrm{~cm}^{-1}$ (Fig. 2a) is obscured by a moderate amount of fringing. These 


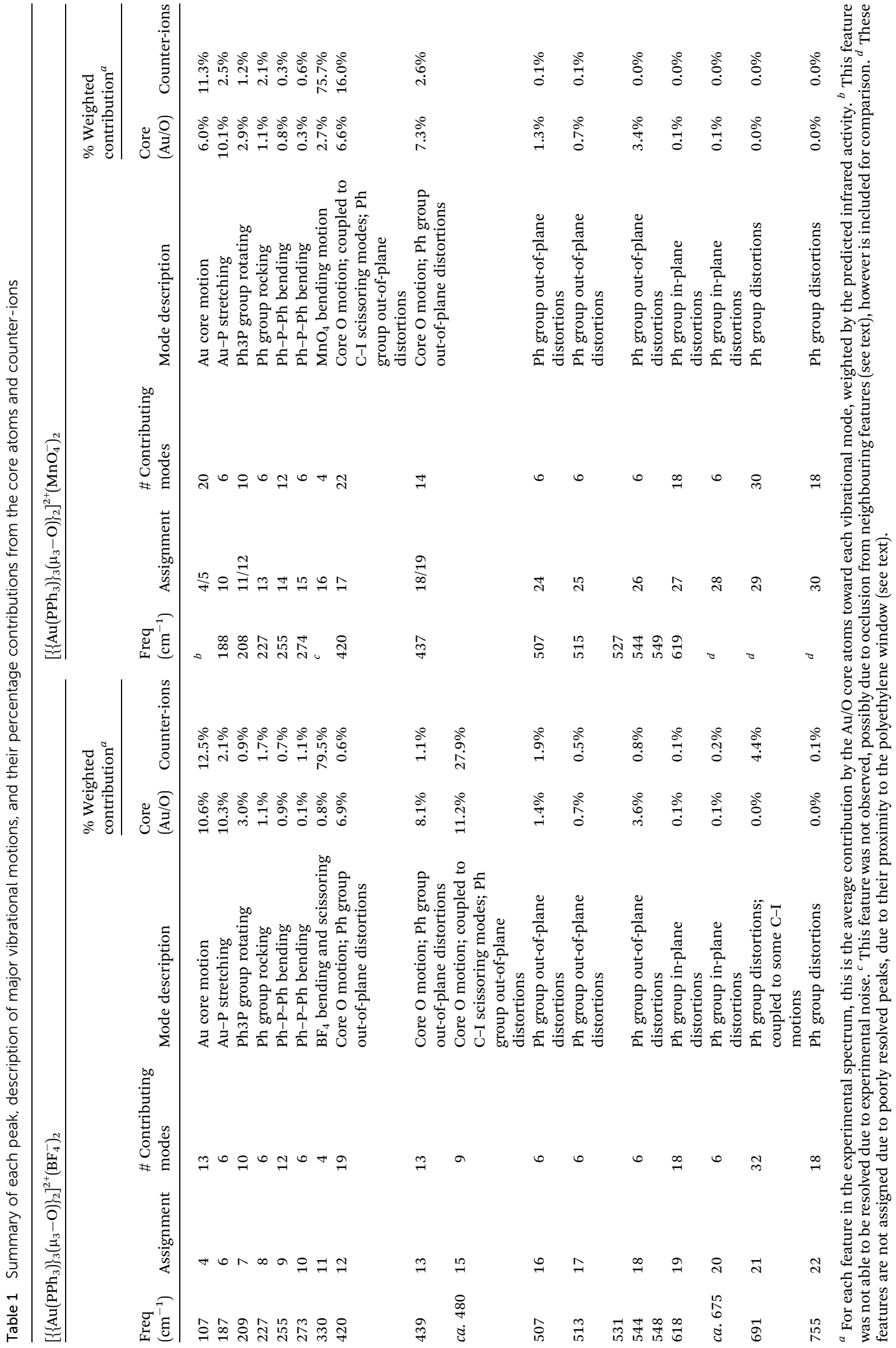


fringing effects are similar to that observed in our previous work for $\mathrm{H}_{4} \mathrm{Ru}_{4}(\mathrm{CO})_{12},{ }^{16}$ and arise due to multiple reflections between parallel reflective surfaces within the experimental setup; efforts to remove them were not successful.

Between 150 and $300 \quad \mathrm{~cm}^{-1}$, the $\left[\left\{\left\{\mathrm{Au}\left(\mathrm{PPh}_{3}\right)\right\}_{3}\left(\mu_{3}-\mathrm{O}\right)\right\}_{2}\right]^{2+}\left(\mathrm{BF}_{4}^{-}\right)_{2}$ spectrum is almost identical to the $\left[\left\{\left\{\mathrm{Au}\left(\mathrm{PPh}_{3}\right)\right\}_{3}\left(\mu_{3}-\mathrm{O}\right)\right\}_{2}\right]^{2+}\left(\mathrm{MnO}_{4}^{-}\right)_{2}$ spectrum with five well resolved peaks in the experimental spectrum appearing in the $\left[\left\{\left\{\mathrm{Au}\left(\mathrm{PPh}_{3}\right)\right\}_{3}\left(\mu_{3}-\mathrm{O}\right)\right\}_{2}\right]^{2+}\left(\mathrm{BF}_{4}^{-}\right)_{2} \quad$ spectrum (and the $\left[\left\{\left\{\mathrm{Au}\left(\mathrm{PPh}_{3}\right)\right\}_{3}\left(\mu_{3}-\mathrm{O}\right)\right\}_{2}\right]^{2+}\left(\mathrm{MnO}_{4}^{-}\right)_{2}$ spectrum $)$ at $187(188), 209$ (208), 227 (227), 255 (255), and $273(274) \mathrm{cm}^{-1}$. The calculated peak at $187(188) \mathrm{cm}^{-1}$ is assigned to peak \#6 (\#10) in the experimental spectrum, arises due to several Au-P stretches that have a high $(>10 \%)$ contribution from the Au core. The features observed at 209 and 227 (208 and 227) $\mathrm{cm}^{-1}$ are tentatively assigned to peaks \#7 and low-energy shoulders (\#11/12), and \#8 (\#13), respectively, from the predicted spectrum. These predicted peaks correspond to numerous rocking motions of the phenyl groups, with little $(<3 \%)$ contribution from either the core or the counter-ions. The experimental peaks at 255 and 273 (255 and 274) $\mathrm{cm}^{-1}$ are assigned to peaks $\# 9$ and \#10 (\#14 and \#15) in the predicted spectra, which both arise due to $\mathrm{Ph}-\mathrm{P}-\mathrm{Ph}$ bending modes.

The experimental spectrum of the $\left[\left\{\left\{\mathrm{Au}\left(\mathrm{PPh}_{3}\right)\right\}_{3^{-}}\right.\right.$ $\left.\left.\left(\mu_{3}-\mathrm{O}\right)\right\}_{2}\right]^{2+}\left(\mathrm{BF}_{4}^{-}\right)_{2}$ cluster within the $300-400 \mathrm{~cm}^{-1}$ region possesses a single large peak occurring at $330 \mathrm{~cm}^{-1}$. This peak is assigned to peak $\# 11$ in the predicted spectrum of $\left[\left\{\left\{\mathrm{Au}\left(\mathrm{PPh}_{3}\right)\right\}_{3}\left(\mu_{3}-\mathrm{O}\right)\right\}_{2}\right]^{2+}\left(\mathrm{BF}_{4}^{-}\right)_{2}$, which is due to two vibrational modes of each of the two $\mathrm{BF}_{4}^{-}$anions. These four vibrational modes, which are predicted to occur at 322, 323, 328, and 329 $\mathrm{cm}^{-1}$, are due to bending and scissoring vibrations of the two $\mathrm{BF}_{4}^{-}$counter-ions. These features are not theoretically predicted for the counter-ion alone in the gas phase, and were only found to appear when counter-ions were explicitly included in the calculation with $\left[\left\{\left\{\mathrm{Au}\left(\mathrm{PPh}_{3}\right)\right\}_{3}\left(\mu_{3}-\mathrm{O}\right)\right\}_{2}\right]^{2+}$. The corresponding $\left[\left\{\left\{\mathrm{Au}\left(\mathrm{PPh}_{3}\right)\right\}_{3}\left(\mu_{3}-\mathrm{O}\right)\right\}_{2}\right]^{2+}\left(\mathrm{MnO}_{4}^{-}\right)_{2}$ experimental spectrum exhibits no corresponding $\mathrm{MnO}_{4}^{-}$experimental feature, though the peak is theoretically predicted to appear at $c a .370 \mathrm{~cm}^{-1}$ (peak\#16), and is likely to be masked by the much more intense peak at $420 \mathrm{~cm}^{-1}$.

Fig. 3a compares the three predicted spectra for the 50-400 $\mathrm{cm}^{-1}$ region, for $\left[\left\{\left\{\mathrm{Au}\left(\mathrm{PPh}_{3}\right)\right\}_{3}\left(\mu_{3}-\mathrm{O}\right)\right\}_{2}\right]^{2+},\left[\left\{\left\{\mathrm{Au}\left(\mathrm{PPh}_{3}\right)\right\}_{3}\left(\mu_{3}-\mathrm{O}\right)\right\}_{2}\right]^{2+}$ $\left(\mathrm{MnO}_{4}^{-}\right)_{2}$, and $\left[\left\{\left\{\mathrm{Au}\left(\mathrm{PPh}_{3}\right)\right\}_{3}\left(\mu_{3}-\mathrm{O}\right)\right\}_{2}\right]^{2+}\left(\mathrm{BF}_{4}^{-}\right)_{2}$. Below $150 \mathrm{~cm}^{-1}$, the three predicted spectra differ markedly, with the $\left[\left\{\left\{\mathrm{Au}\left(\mathrm{PPh}_{3}\right)\right\}_{3}\left(\mu_{3}-\mathrm{O}\right)\right\}_{2}\right]^{2+}$ predicted spectrum having much smaller intensities within this region, while $\left[\left\{\left\{\mathrm{Au}\left(\mathrm{PPh}_{3}\right)\right\}_{3^{-}}\right.\right.$ $\left.\left.\left(\mu_{3}-\mathrm{O}\right)\right\}_{2}\right]^{2+}\left(\mathrm{BF}_{4}^{-}\right)_{2}$ and $\left[\left\{\left\{\mathrm{Au}\left(\mathrm{PPh}_{3}\right)\right\}_{3}\left(\mu_{3}-\mathrm{O}\right)\right\}_{2}\right]^{2+}\left(\mathrm{MnO}_{4}^{-}\right)_{2}$ show differing intensities around $125-140 \mathrm{~cm}^{-1}$. Between 125 and $150 \mathrm{~cm}^{-1}$ there is expected to be considerable contribution to the vibrations due to the counter-ions in both the $\left[\left\{\left\{\mathrm{Au}\left(\mathrm{PPh}_{3}\right)\right\}_{3}\left(\mu_{3}-\mathrm{O}\right)\right\}_{2}\right]^{2+}\left(\mathrm{BF}_{4}^{-}\right)_{2}$ and $\left[\left\{\left\{\mathrm{Au}\left(\mathrm{PPh}_{3}\right)\right\}_{3}\left(\mu_{3}-\mathrm{O}\right)\right\}_{2}\right]^{2+}$ $\left(\mathrm{MnO}_{4}^{-}\right)_{2}$ cases, which gives rise to these intensity differences, although these differences appear dampened in the experimental spectrum. Between 150 and $300 \mathrm{~cm}^{-1}$, there is general similarity between the three theoretical spectra, in both intensities and peak locations, while between 300 and $400 \mathrm{~cm}^{-1}$, a peak is predicted for both $\left[\left\{\left\{\mathrm{Au}\left(\mathrm{PPh}_{3}\right)\right\}_{3}\left(\mu_{3}-\mathrm{O}\right)\right\}_{2}\right]^{2+}\left(\mathrm{BF}_{4}^{-}\right)_{2}(330$
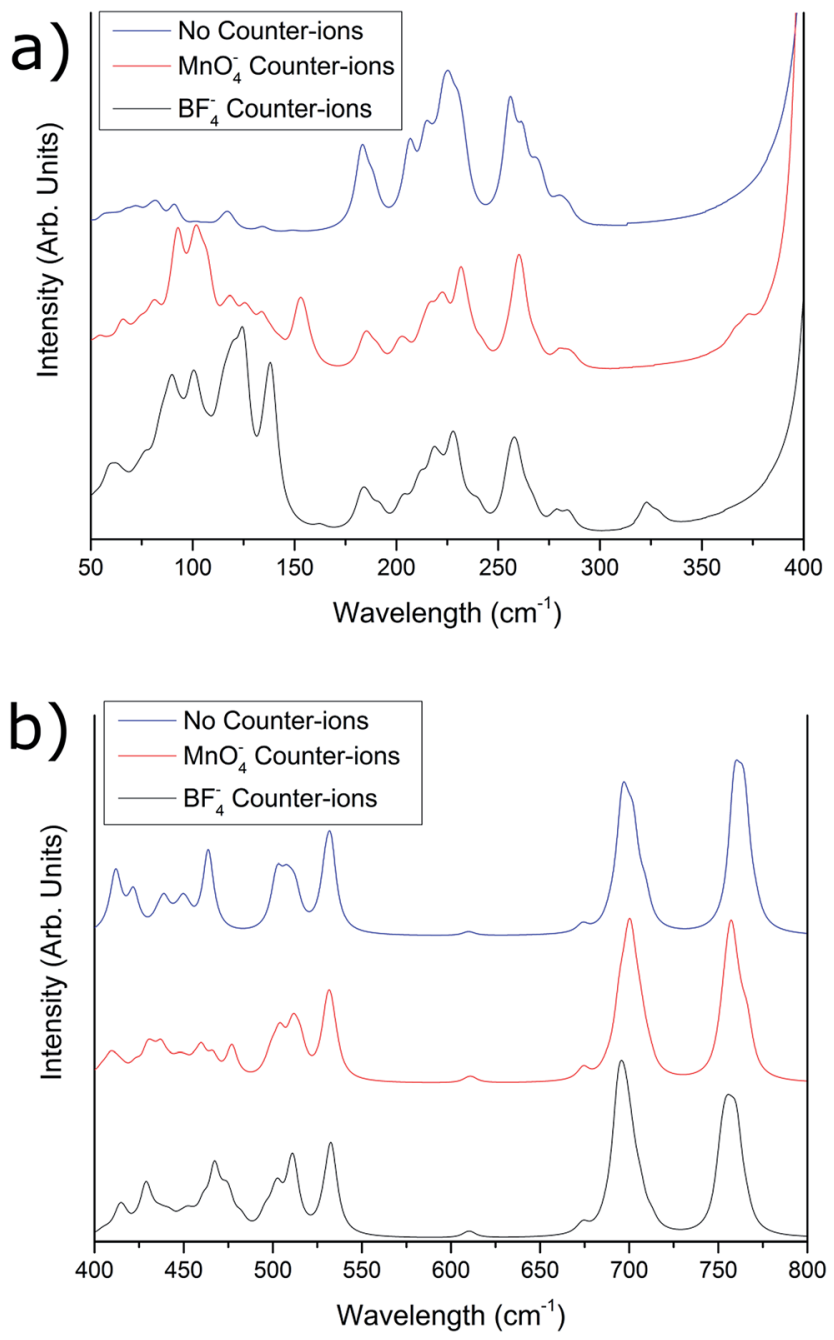

Fig. 3 Comparison between theoretically calculated far-IR spectra of the tris(triphenylphosphinegold)oxonium salts with no counter-ions present (blue), $\mathrm{MnO}_{4}^{-}$counter-ions present (red), and $\mathrm{BF}_{4}^{-}$counterions present (black), in the (a) $50-400 \mathrm{~cm}^{-1}$ region and (b) $400-800$ $\mathrm{cm}^{-1}$ region. The simulated spectra have been corrected by eqn (1).

$\left.\mathrm{cm}^{-1}\right)$ and $\left[\left\{\left\{\mathrm{Au}\left(\mathrm{PPh}_{3}\right)\right\}_{3}\left(\mu_{3}-\mathrm{O}\right)\right\}_{2}\right]^{2+}\left(\mathrm{MnO}_{4}^{-}\right)_{2}\left(370 \mathrm{~cm}^{-1}\right)$ which is absent in the spectrum calculated for $\left[\left\{\left\{\mathrm{Au}\left(\mathrm{PPh}_{3}\right)\right\}_{3^{-}}\right.\right.$ $\left.\left.\left(\mu_{3}-\mathrm{O}\right)\right\}_{2}\right]^{2+}$ without counter-ions (vide supra).

\section{$400-800 \mathrm{~cm}^{-1}$ region}

The experimental spectra of $\left[\left\{\left\{\mathrm{Au}\left(\mathrm{PPh}_{3}\right)\right\}_{3}\left(\mu_{3}-\mathrm{O}\right)\right\}_{2}\right]^{2+}\left(\mathrm{BF}_{4}^{-}\right)_{2}$ and $\left[\left\{\left\{\mathrm{Au}\left(\mathrm{PPh}_{3}\right)\right\}_{3}\left(\mu_{3}-\mathrm{O}\right)\right\}_{2}\right]^{2+}\left(\mathrm{MnO}_{4}^{-}\right)_{2}$ within the $400-800 \mathrm{~cm}^{-1}$ region are shown in Fig. $1 \mathrm{~b}$ and $2 \mathrm{~b}$, respectively. Both spectra exhibit baseline between $700-750 \mathrm{~cm}^{-1}$ due to the complete absorption of the polyethylene used as the diluting agent in this region. $^{26,27}$ The experimental spectrum between 400 and 500 $\mathrm{cm}^{-1}$ for $\left[\left\{\left\{\mathrm{Au}\left(\mathrm{PPh}_{3}\right)\right\}_{3}\left(\mu_{3}-\mathrm{O}\right)\right\}_{2}\right]^{2+}\left(\mathrm{BF}_{4}^{-}\right)_{2}$ (and for the $\left[\left\{\left\{\mathrm{Au}\left(\mathrm{PPh}_{3}\right)\right\}_{3}\left(\mu_{3}-\mathrm{O}\right)\right\}_{2}\right]^{2+}\left(\mathrm{MnO}_{4}^{-}\right)_{2}$ spectrum) exhibits peaks at $420(420) \mathrm{cm}^{-1}, 438(439) \mathrm{cm}^{-1}$, and a shoulder at $c a .480$ (ca. 480) $\mathrm{cm}^{-1}$. For the $\left[\left\{\left\{\mathrm{Au}\left(\mathrm{PPh}_{3}\right)\right\}_{3}\left(\mu_{3}-\mathrm{O}\right)\right\}_{2}\right]^{2+}\left(\mathrm{BF}_{4}^{-}\right)_{2}$ spectrum, these peaks are assigned to theoretical peaks $\# 12, \# 13$, and \#15, respectively, which are due to Ph group out-of-plane distortions, 
as well as a large contribution from core O motion (up to $11 \%$ for peak \#15). Theoretical peak \#15 is also predicted to possess a large component of counter-ion motion, almost $28 \%$ of the total atomic motion. The $\left[\left\{\left\{\mathrm{Au}\left(\mathrm{PPh}_{3}\right)\right\}_{3}\left(\mu_{3}-\mathrm{O}\right)\right\}_{2}\right]^{2+}\left(\mathrm{MnO}_{4}^{-}\right)_{2}$ peaks at 420 and $437 \mathrm{~cm}^{-1}$ are assigned to peaks \#17 and \#18/\#19, respectively, which arise from $\mathrm{Ph}$ group out-of-plane distortions and core $\mathrm{O}$ atomic motion, similar to the $\left[\left\{\left\{\mathrm{Au}\left(\mathrm{PPh}_{3}\right)\right\}_{3^{-}}\right.\right.$ $\left.\left.\left(\mu_{3}-\mathrm{O}\right)\right\}_{2}\right]^{2+}\left(\mathrm{BF}_{4}^{-}\right)_{2}$ spectrum. The former of these peaks is predicted to possess a significant $16 \%$ contribution of atomic motion from the counter-ions. The shoulder at $c a .480 \mathrm{~cm}^{-1}$ in the experimental $\left[\left\{\left\{\mathrm{Au}\left(\mathrm{PPh}_{3}\right)\right\}_{3}\left(\mu_{3}-\mathrm{O}\right)\right\}_{2}\right]^{2+}\left(\mathrm{MnO}_{4}^{-}\right)_{2}$ spectrum cannot be unambiguously identified, so is left unassigned.

The spectrum between 500 and $600 \mathrm{~cm}^{-1}$ for $\left[\left\{\left\{\mathrm{Au}\left(\mathrm{PPh}_{3}\right)\right\}_{3}\left(\mu_{3}-\mathrm{O}\right)\right\}_{2}\right]^{2+}\left(\mathrm{BF}_{4}^{-}\right)_{2}$ (and for the $\left[\left\{\left\{\mathrm{Au}\left(\mathrm{PPh}_{3}\right)\right\}_{3}\left(\mu_{3}-\mathrm{O}\right)\right\}_{2}\right]^{2+}$ $\left(\mathrm{MnO}_{4}^{-}\right)_{2}$ spectrum) shows two doublets at 507 \& 513 (507 \& 515) $\mathrm{cm}^{-1}$, and $544 \& 548(544 \& 549) \mathrm{cm}^{-1}$, with a smaller intensity peak between them at $531(527) \mathrm{cm}^{-1}$. The former of the doublets is assigned to peaks \#16 and \#17 (\#24 and \#25) in the theoretical spectrum, while the higher energy of the doublets are assigned to peak \#18 (\#26). These peaks are predicted to arise due to eighteen moderate intensity $\left(<100 \mathrm{~km} \mathrm{~mol}^{-1}\right)$ phenyl group out-of-plane distortions, with little contribution $(<4 \%)$ from the Au core or the counter-ions. The peak which is observed at $531(527) \mathrm{cm}^{-1}$ is unassigned to any peaks within the theoretical spectrum, and is of unknown origin.

Above $600 \mathrm{~cm}^{-1}$, three features are observed in the spectrum of $\left[\left\{\left\{\mathrm{Au}\left(\mathrm{PPh}_{3}\right)\right\}_{3}\left(\mu_{3}-\mathrm{O}\right)\right\}_{2}\right]^{2+}\left(\mathrm{BF}_{4}^{-}\right)_{2}$, at $618 \mathrm{~cm}^{-1}, 691 \mathrm{~cm}^{-1}$, and $755 \mathrm{~cm}^{-1}$, as well as a shoulder at $c a .675 \mathrm{~cm}^{-1}$. The low intensity feature at $618 \mathrm{~cm}^{-1}$ matches a similar feature in the $\left[\left\{\left\{\mathrm{Au}\left(\mathrm{PPh}_{3}\right)\right\}_{3}\left(\mu_{3}-\mathrm{O}\right)\right\}_{2}\right]^{2+}\left(\mathrm{MnO}_{4}^{-}\right)_{2}$ spectrum at $619 \mathrm{~cm}^{-1}$, and are assigned to peaks \#19 and \#27, respectively, within the theoretical spectra. These peaks are predicted to arise due to eighteen very low infrared intensity $\left(<5 \mathrm{~km} \mathrm{~mol}^{-1}\right)$ vibrational modes, which are due to $\mathrm{Ph}$ group in-plane distortions.

The $\left[\left\{\left\{\mathrm{Au}\left(\mathrm{PPh}_{3}\right)\right\}_{3}\left(\mu_{3}-\mathrm{O}\right)\right\}_{2}\right]^{2+}\left(\mathrm{BF}_{4}^{-}\right)_{2}$ peaks observed at 691 and $755 \mathrm{~cm}^{-1}$ are assigned to peaks \#21 and \#22 in the theoretical spectrum, and are predicted to arise due to $\mathrm{Ph}$ group distortions, with very little contribution $(<0.1 \%)$ due to either the $\mathrm{Au}$ core or the counter-ions $(<5 \%)$. The corresponding $\left[\left\{\left\{\mathrm{Au}\left(\mathrm{PPh}_{3}\right)\right\}_{3}\left(\mu_{3}-\mathrm{O}\right)\right\}_{2}\right]^{2+}\left(\mathrm{MnO}_{4}^{-}\right)_{2}$ features display significant noise due to the polyethylene absorption window within this region, however similar peaks to the $\left[\left\{\left\{\mathrm{Au}\left(\mathrm{PPh}_{3}\right)\right\}_{3^{-}}\right.\right.$ $\left.\left.\left(\mu_{3}-\mathrm{O}\right)\right\}_{2}\right]^{2+}\left(\mathrm{BF}_{4}^{-}\right)_{2}$ spectrum are predicted (peaks \#29 and \#30), and are found to arise similarly due to $\mathrm{Ph}$ group distortions. Finally, a shoulder observed at $c a .675 \mathrm{~cm}^{-1}$ within the $\left[\left\{\left\{\mathrm{Au}\left(\mathrm{PPh}_{3}\right)\right\}_{3}\left(\mu_{3}-\mathrm{O}\right)\right\}_{2}\right]^{2+}\left(\mathrm{BF}_{4}^{-}\right)_{2}$ spectrum is assigned to predicted peak \#20, also due to $\mathrm{Ph}$ group distortions.

The predicted spectra for $\left[\left\{\left\{\mathrm{Au}\left(\mathrm{PPh}_{3}\right)\right\}_{3}\left(\mu_{3}-\mathrm{O}\right)\right\}_{2}\right]^{2+}$, $\left[\left\{\left\{\mathrm{Au}\left(\mathrm{PPh}_{3}\right)\right\}_{3}\left(\mu_{3}-\mathrm{O}\right)\right\}_{2}\right]^{2+}\left(\mathrm{BF}_{4}^{-}\right)_{2}, \quad$ and $\quad\left[\left\{\left\{\mathrm{Au}\left(\mathrm{PPh}_{3}\right)\right\}_{3}\left(\mu_{3}-\mathrm{O}\right)\right\}_{2}\right]^{2+}$ $\left(\mathrm{MnO}_{4}^{-}\right)_{2}$ in the $400-800 \mathrm{~cm}^{-1}$ region are compared in Fig. $3 \mathrm{~b}$. Differences in relative intensities are observed for the 400-500 $\mathrm{cm}^{-1}$ region, which is attributed to differences in the counter-ion contribution toward the intensity of the peaks within this region, as discussed above. Above $500 \mathrm{~cm}^{-1}$, no significant differences within the spectra were predicted to occur. Experimentally, almost no differences were observed between the $\left[\left\{\left\{\mathrm{Au}\left(\mathrm{PPh}_{3}\right)\right\}_{3^{-}}\right.\right.$ $\left.\left.\left(\mu_{3}-\mathrm{O}\right)\right\}_{2}\right]^{2+}\left(\mathrm{BF}_{4}^{-}\right)_{2}$ and $\left[\left\{\left\{\mathrm{Au}\left(\mathrm{PPh}_{3}\right)\right\}_{3}\left(\mu_{3}-\mathrm{O}\right)\right\}_{2}\right]^{2+}\left(\mathrm{MnO}_{4}^{-}\right)_{2}$ spectra, outside of the $330 \mathrm{~cm}^{-1}$ peak present in the $\left[\left\{\left\{\mathrm{Au}\left(\mathrm{PPh}_{3}\right)\right\}_{3}\left(\mu_{3}-\mathrm{O}\right)\right\}_{2}\right]^{2+}\left(\mathrm{BF}_{4}^{-}\right)_{2}$ spectrum. This suggests a dampening of all counter-ion vibrational modes when the sample is in the solid phase, removing the effect of these modes on the infrared spectrum.

\section{Binding energies}

The dimerization of the $\left[\left\{\left\{\mathrm{Au}\left(\mathrm{PPh}_{3}\right)\right\}_{3}\left(\mu_{3}-\mathrm{O}\right)\right\}_{2}\right]^{2+}$ species involves the formation of two $\mathrm{Au}-\mathrm{Au}$ bonds across one edge of the $\mathrm{Au}_{3}$ trimer. The two monomers are bound centrosymmetrically, with the six gold atoms forming a ring in a chair conformation (see Fig. S1-S3; ESI $\dagger$ ). Within the monomer, the triphenylphosphine ligands are positioned such that an edge of the $\mathrm{Au}_{3}$ moity is exposed, facilitating the dimerization of the species with minimal ligand repositioning, hence very little bond strain is anticipated to accompany this. The energy of dimerization of the $\left[\left\{\left\{\mathrm{Au}\left(\mathrm{PPh}_{3}\right)\right\}_{3}\left(\mu_{3}-\mathrm{O}\right)\right\}_{2}\right]^{2+}$ system is calculated to be $1.10 \mathrm{eV}$ when no counter-ions are present. With the addition of counter-ions, the energy increases markedly; for the dimer $\left[\left\{\left\{\mathrm{Au}\left(\mathrm{PPh}_{3}\right)\right\}_{3}\left(\mu_{3}-\mathrm{O}\right)\right\}_{2}\right]^{2+}$ system with an $\mathrm{MnO}_{4}^{-}$counterion, the energy of dimerization is predicted to be $3.20 \mathrm{eV}$, and $3.06 \mathrm{eV}$ for the $\mathrm{BF}_{4}^{-}$counter-ion. This significant increase in dimerization energy can be attributed to the electrostatic repulsion between the monomers when no counter-ion is present, resulting in a much less favourable dimerization interaction.

For both the $\left[\left\{\left\{\mathrm{Au}\left(\mathrm{PPh}_{3}\right)\right\}_{3}\left(\mu_{3}-\mathrm{O}\right)\right\}_{2}\right]^{2+}\left(\mathrm{BF}_{4}^{-}\right)_{2}$ and $\left[\left\{\left\{\mathrm{Au}\left(\mathrm{PPh}_{3}\right)\right\}_{3}\left(\mu_{3}-\mathrm{O}\right)\right\}_{2}\right]^{2+}\left(\mathrm{MnO}_{4}^{-}\right)_{2}$ systems, the binding energy of the respective counter-ions was calculated by the stepwise removal of the two counter-ions. For $\left[\left\{\left\{\mathrm{Au}\left(\mathrm{PPh}_{3}\right)\right\}_{3}\left(\mu_{3}-\mathrm{O}\right)\right\}_{2}\right]^{2+}\left(\mathrm{BF}_{4}^{-}\right)_{2}$, this was determined to be 3.06 $\mathrm{eV}$ and $4.65 \mathrm{eV}$ for the removal of the first and second counterion, respectively. For $\left[\left\{\left\{\mathrm{Au}\left(\mathrm{PPh}_{3}\right)\right\}_{3}\left(\mu_{3}-\mathrm{O}\right)\right\}_{2}\right]^{2+}\left(\mathrm{MnO}_{4}^{-}\right)_{2}$, this is slightly higher at $3.15 \mathrm{eV}$ and $4.74 \mathrm{eV}$, respectively. Where the systems are not dimerized, the removal of $\mathrm{BF}_{4}^{-}$from $\left[\left\{\left\{\mathrm{Au}\left(\mathrm{PPh}_{3}\right)\right\}_{3}\left(\mu_{3}-\mathrm{O}\right)\right\}_{2}\right]^{2+}$ is calculated at a lower $2.87 \mathrm{eV}$, while the removal of $\mathrm{MnO}_{4}^{-}$is predicted to be $2.90 \mathrm{eV}$.

The far-infrared vibrational spectrum of the monomer species differs from that of the dimers (see Fig. S4; ESI†). In particular, large differences are predicted between 400 and $475 \mathrm{~cm}^{-1}$, with several features absent from the monomer spectrum that are present in the dimer spectrum. As well, above $475 \mathrm{~cm}^{-1}$ all features are expected to display significant differences in relative intensities, between the monomer and dimer spectra.

\section{Conclusions}

The far-infrared spectrum of $\left[\left\{\left\{\mathrm{Au}\left(\mathrm{PPh}_{3}\right)\right\}_{3}\left(\mu_{3}-\mathrm{O}\right)\right\}_{2}\right]^{2+}\left(\mathrm{BF}_{4}^{-}\right)_{2}$ is found to possess a large feature at $330 \mathrm{~cm}^{-1}$, attributable to several counter-ion vibrational modes, which are only correctly predicted upon explicit inclusion of counter-ions within the calculations. A feature around $107 \mathrm{~cm}^{-1}$ was observed in the $\left[\left\{\left\{\mathrm{Au}\left(\mathrm{PPh}_{3}\right)\right\}_{3}\left(\mu_{3}-\mathrm{O}\right)\right\}_{2}\right]^{2+}\left(\mathrm{BF}_{4}^{-}\right)_{2}$ infrared spectrum, which was assigned to 21 distinct vibrational modes arising due to $\mathrm{Au}-\mathrm{Au}$ bond stretching, and motion of the Au core. Within the 400-800 
$\mathrm{cm}^{-1}$ region, little dependence of the theoretical spectra on the nature of the counter-ions was predicted, while in the 50-400 $\mathrm{cm}^{-1}$ region, the relative intensities of predicted vibrational modes was found to depend heavily on the presence and nature of the counter-ions. Finally, the dimerization energies of both $\left[\left\{\left\{\mathrm{Au}\left(\mathrm{PPh}_{3}\right)\right\}_{3}\left(\mu_{3}-\mathrm{O}\right)\right\}_{2}\right]^{2+}\left(\mathrm{BF}_{4}^{-}\right)_{2}$ and $\quad\left[\left\{\left\{\mathrm{Au}\left(\mathrm{PPh}_{3}\right)\right\}_{3}\left(\mu_{3}-\mathrm{O}\right)\right\}_{2}\right]^{2+}$ $\left(\mathrm{MnO}_{4}^{-}\right)_{2}$ were calculated, and found to be $3.06 \mathrm{eV}$ and $3.20 \mathrm{eV}$, respectively, when the counter-ions were explicitly included within the calculation, and only $1.10 \mathrm{eV}$ when the counter-ions were not included.

\section{Acknowledgements}

This research was undertaken on the High-Resolution Infrared beamline at the Australian Synchrotron, Victoria, Australia. Financial support from the Centre for Energy Technologies at the University of Adelaide, the MacDiarmid Institute for Advanced Materials and Nanotechnology, the University of Canterbury and the University of Malaya is gratefully acknowledged. Computing resources provided by the National Computational Infrastructure (NCI) Facility and eResearch SA is also gratefully acknowledged. The authors would also like to thank Dr Dominique Appadoo for his advice on recording the infra-red spectra at the Australian Synchrotron.

\section{References}

1 H. Schmidbaur and A. Schier, Chem. Soc. Rev., 2012, 41, 370412.

2 A. Nesmeyanov, E. Perevalova, D. Lemenovskii, V. Dyadchenko and K. Grandberg, Russ. Chem. Bull., 1974, 23, 1587-1589.

3 A. Nesmeyanov, E. Perevalova, Y. T. Struchkov, M. Y. Antipin, K. Grandberg and V. Dyadhenko, J. Organomet. Chem., 1980, 201, 343-349.

4 E. Smyslova, E. Perevalova, V. Dyadchenko, K. Grandberg, Y. L. Slovokhotov and Y. T. Struchkov, J. Organomet. Chem., 1981, 215, 269-279.

5 E. Perevalova, K. Grandberg, V. Dyadchenko and T. Baukova, J. Organomet. Chem., 1981, 217, 403-413.

6 E. Perevalova, T. Baukova, M. Sazonenko and K. Grandberg, Russ. Chem. Bull., 1985, 34, 1722-1726.

7 K. Grandberg and V. Dyadchenko, J. Organomet. Chem., 1994, 474, 1-21.

8 T. Baukova, Y. L. Slovokhotov and Y. T. Struchkov, J. Organomet. Chem., 1981, 220, 125-137.

9 T. Baukova, Y. L. Slovokhotov and Y. T. Struchkov, J. Organomet. Chem., 1981, 221, 375-384.

10 A. Peregudov, L. Usatova, E. Smyslova and D. Kravtsov, Russ. Chem. Bull., 1994, 43, 125-129.

11 H. Schmidbaur, A. Grohmann, M. E. Olmos and A. Schier, Patai's Chemistry of Functional Groups, 1999.
12 B. Djordjevic, K. A. Porter, S. Nogai, A. Schier and H. Schmidbaur, Organometallics, 2003, 22, 5336-5344.

13 M. I. Bruce and B. K. Nicholson, J. Chem. Soc., Chem. Commun., 1982, 1141-1143.

14 M. I. Bruce and B. K. Nicholson, Organometallics, 1984, 3, 101-108.

15 J. F. Alvino, T. Bennett, D. P. Anderson, B. Donoeva, D. Ovoshchnikov, R. Adnan, D. R. Appadoo, V. Golovko, G. G. Andersson and G. F. Metha, RSC Adv., 2013, 3, 22140-22149.

16 T. Bennett, R. H. Adnan, J. F. Alvino, V. Golovko, G. G. Andersson and G. F. Metha, Inorg. Chem., 2014, 53, 4340-4349.

17 Y. Zhao and D. G. Truhlar, Theor. Chem. Acc., 2008, 120, 215241.

18 T. Dunning Jr and P. Hay, Mod. Theor. Chem., 1977, 3, 1-28. 19 P. J. Hay and W. R. Wadt, J. Chem. Phys., 1985, 82, 270-283. 20 P. J. Hay and W. R. Wadt, J. Chem. Phys., 1985, 82, 299-310. 21 W. R. Wadt and P. J. Hay, J. Chem. Phys., 1985, 82, 284-298. 22 M. J. Frisch; G. W. Trucks; H. B. Schlegel; G. E. Scuseria; M. A. Robb; J. R. Cheeseman; G. Scalmani; V. Barone; B. Mennucci; G. A. Petersson; H. Nakatsuji; M. Caricato; X. Li; H. P. Hratchian; A. F. Izmaylov; J. Bloino; G. Zheng; J. L. Sonnenberg; M. Hada; M. Ehara; K. Toyota; R. Fukuda; J. Hasegawa; M. Ishida; T. Nakajima; Y. Honda; O. Kitao; H. Nakai; T. Vreven; J. J. A. Montgomery; J. E. Peralta; F. Ogliaro; M. Bearpark; J. J. Heyd; E. Brothers; K. N. Kudin; V. N. Staroverov; R. Kobayashi; J. Normand; K. Raghavachari; A. Rendell; J. C. Burant; S. S. Iyengar; J. Tomasi; M. Cossi; N. Rega; N. J. Millam; M. Klene; J. E. Knox; J. B. Cross; V. Bakken; C. Adamo; J. Jaramillo; R. Gomperts; R. E. Stratmann; O. Yazyev; A. J. Austin; R. Cammi; C. Pomelli; J. W. Ochterski; R. L. Martin; K. Morokuma; V. G. Zakrzewski; G. A. Voth; P. Salvador; J. J. Dannenberg; S. Dapprich; A. D. Daniels; Ö. Farkas; J. B. Foresman; J. V. Ortiz; J. Cioslowski and D. J. FoxGaussian 09 (Revision D.01), Gaussian 09 (Revision D.01), Gaussian, Inc.: Wallingford CT, 2009.

23 L. Kuz'mina, A. Churakov, K. Grandberg and J. Howard, J. Chem. Crystallogr., 2005, 35, 635-640.

24 F. Allen, Acta Crystallogr., Sect. B: Struct. Sci., 2002, 58, 380388.

25 L. Lin, P. Claes, P. Gruene, G. Meijer, A. Fielicke, M. T. Nguyen and P. Lievens, ChemPhysChem, 2010, 11, 1932-1943.

26 S. Krimm, C. Liang and G. Sutherland, J. Chem. Phys., 1956, 25, 549-562.

27 H. Thompson and P. Torkington, Trans. Faraday Soc., 1945, 41, 246b-260. 